\title{
SOCIALISTS AND BUREAUCRATS: THE BLUM GOVERNMENT AND THE FRENCH ADMINISTRATION, $1936-37$
}

The failure of the Popular Front government of 1936-1937 was at least two-fold: from the national standpoint it was able neither to formulate a foreign policy of anti-fascism nor to bring France out of the economic crisis; from the narrower political perspective it was unable to prevent a growing sense of disillusionment and recrimination among its constituents. Both aspects have received increasing attention from historians in recent years, although not always with sufficient regard for the extent to which the two problems might be separable. Greater intervention on behalf of the Spanish Republicans, for example, might not have saved the Spanish Republic, but even so would have gone far toward satisfying Blum's constituents and blunting communist criticism of his government. Abandonment of the forty-hour week, on the other hand, while adding to the deceptions of the left, might have permitted the achievement of the economic upturn upon which the hopes of the Popular Front ultimately rested. ${ }^{1}$ Spain and finances war and economics, the twin chief concerns of western civilization in our century as A. J. P. Taylor has facetiously suggested - are the issues in terms of which most analysts of Blum's double failure have proceeded. But there is another which may have been equally important, and which appears to have been of greater significance in the eyes of contemporaries. This was the question of the relationship of the Blum government and the French administration. The increasingly blurred distinction between politics and administration characteristic of contemporary Gaullism, as well as the rigidity and resistance to innovation typical of the crisis-prone French bureaucratic style, suggest in any case a re-evaluation of the recent past in terms what Michel Crozier has aptly called "the bureaucratic phenomenon".2

Viewed from the perspective of the inter-action between the un-

1 This is the opinion of Alfred Sauvy, Histoire économique de la France entre les deux guerres, II (Paris, 1967).

2 See Michel Crozier's modern classic, The Bureaucratic Phenomenon (Chicago, 1970), and Charles Debbasch, L'Administration au Pouvoir (Paris, 1969). 
schooled Socialist ministers of 1936 and the traditional French administrative structure, a new way of looking at the Popular Front's difficulties emerges. On the one hand it can be argued that a root cause of Blum's failure, and an explanation for the cautious conservatism of his government's actions, stems from the inherent resistance to innovation of the conservatively biased career civil service which the Socialist government proved unable to counter by the one means available to it - finding the personnel appropriate to its policies. This may appear a doubtful proposition, and the evidence is by no means exhaustive, but it merits careful consideration nevertheless. On the other hand, from the standpoint of the relationship of the government to its left-wing constituents, we are on firmer ground. Failure of the Blum government to "democratize" the French administration appears almost certainly to have been the most critical single source of disillusionment with the experiment among the militants of Blum's own party, if not for supporters of the Popular Front as a whole.

That this is so becomes clear from a perusal of the Socialist party's provincial press of the era. Of some 50 weekly departmental newspapers of Socialist federations extant in the collection of the Bibliotheqque Nationale, virtually every one criticized the Blum government at some point or other during its year in power for failure to democratize the administration, "épurer les hautes administrations de l'état". On the other hand, as has been noted elsewhere, criticism of Blum's Spanish policies was confined to a minority in the Socialist party and characteristic of federations in which the party's dissident factions were strong, or which were located near the Spanish frontier. ${ }^{1}$ The Blum government's economic policies, by contrast, were rarely even discussed in the Socialist provincial press, much less criticized. In retrospect it is perhaps no more surprising that historians have failed to deal with the bureaucratic question than that it appeared so singularly important in the eyes of contemporaries. If the weight of the Napoleonic bureaucracy of France were felt daily by politically conscious local elites constantly entangled with courts and prefectures, the historian has nevertheless been at a loss to evaluate the nature and accuracy of the charges and complaints of the period. The most exaggerated rhetorical claims about the insidiousness of governmental personnel were commonplace in the 1930's. A widely syndicated article by Paul Allard, for example, indicted the Inspection des Finances as the stronghold of a virtual "mafia" whose members were described as

1 See Nathanael Greene, Crisis and Decline: The French Socialist Party in the Popular Front Era (Ithaca, 1969), pp. 175-192, for a study of the impact of the Spanish Civil War on local federations of the SFIO. 
secret masters of the State. All were graduates of the highly suspect Ecole des Sciences Politiques where "conservative indoctrination [...] rigidly suppressed any new ideas".

"The ministers of the republic, subordinate to the control of parliament, no longer count for anything. [...] Alongside them, beyond them, there is a committee of so-called control, irresponsible, which dispossesses the minister of the last financial powers of which he disposed. [...] The elected official of the nation is no more than a figurehead, a mannequin, a marionette in their hands. [...] Masters of the State, the Inspectors are often traitors to the State". 1

The charge that ministers were manipulated by career civil servants was of long standing; of greater concern was the claim that the prefectoral corps had become a stronghold of anti-republican sentiment. Prefects were widely accused of failing to cooperate with local elective bodies, or of deliberately sabotaging government directives. La Tribune des Fonctionnaires, organ of the union of government workers, saw as a remedy nothing less than the action of Premier Dufaure, who, in 1879, after the resignation of President MacMahon, replaced 85 prefects and 280 sub-prefects, and followed this with similar activity in the diplomatic corps, the army, and the magistrature. Complaints even focused, as unlikely as it may seem, on the postal service. It is no wonder that the most enthusiastic reaction at any point of Léon Blum's May 10, 1936 speech to the National Council of the Socialist party before taking office was reserved for his promise to cause a "republican wind" (souffle républicain) to pass through the administrative services of the State. ${ }^{2}$ No promise made by the Socialist leader was subsequently to become the cause for greater regret and embarrassment.

Not the least of the paradoxes of the era was the greater frequency of local socialist protest in those bureaucratic services which were of lesser import from the national standpoint. Thus the army, the foreign service, and the Inspectorate of Finance probably had the greatest impact on the Blum government's crucial policy decisions; but it was the prefectoral corps, the judiciary, the post office, and the colonial bureaucracy which bore the brunt of criticism by Socialist militants. Of the domestic services the prefectoral corps, with its crucial powers of tutelage over the actions of municipalities and communes, was

1 La Tribune des Fonctionnaires, June 6, 1936.

2 The author was privileged to hear a recording of Léon Blum's speech during an interview with Madame Blum on June 4, 1966. The remark was received with enthusiastic, sustained applause in interruption of the speech. 
clearly most at issue. The Socialist party numbered 865 mayors and 12,000 municipal councillors in its ranks in $1936 . .^{1}$ It is unfortunately almost impossible to gauge the accuracy of Socialist party complaints about the prefects as a whole. These ranged from charges of simple disrespect shown to local Socialists by the prefect, or manifestations of sympathy with rightist organizations, to more serious complaints of electoral manipulation, fraud, and sabotage of the Popular Front program. What seems clear is that the Blum government felt in no position to proceed with the kind of "massacre" of the corps characteristic, not of changes of government in France in the past, but rather of changes of regime. ${ }^{2}$ On the other hand some sort of prefectoral "waltz", perhaps on the scale of that carried out by Herriot in 1924, was eagerly awaited and seemed to be clearly in the cards. It was never to occur.

There was nevertheless ample justification for such action from the perspective of the party. In the Drome, for example, the Prefect Henri Graux had outraged local Socialists by attending meetings of the "Laroquist" Union Nationale des Combattants, by calling out police against striking workers, and by permitting demonstrations of the Croix de Feu. In the Finistère the Prefect Larquet was reported to have stood by attentively at a meeting of the UNC while orators "slandered" the Popular Front, and then managed to be away hunting during a visit of the Blum government's naval minister, GasnierDuparc. In the Dordogne the prefect was charged with hiring "rightist cronies" in prefectoral offices; in the Charente he allegedly appointed members of the Croix de Feu to clerical jobs and then covered up acts of embezzlement by his rightist subordinates. ${ }^{3}$ Minor prefectoral posts, one may safely assume, might reasonably have been expected to go to Socialists, given the coincidence of high unemployment and a Socialist government in power. Similar charges against prefects appeared in the Socialist press in the Alpes-Maritimes, Marne, Saône-et-Loire, BassesPyrénées, Morbihan, Deux-Sèvres, and the Vosges. ${ }^{4}$ There were prefects

1 J. Ferretti, Ce qu'est le parti socialiste (Paris, 1936), p. 26.

2 On this question see Brian Chapman, The Prefects and Provincial France (London, 1955), and Jeanne Siwek-Pouydesseau, Le Corps préfectoral sous la Troisième et la Quatrième République (Paris, 1969).

${ }^{3}$ La Volonté Socialiste, July 4, October 10, 1936; Le Breton Socialiste, July 18 and September 19, 1936; La Voix Socialiste, July 18, August 8 and September 19, 1936.

4 L'Alerte (Nice) thought the prefect to have been "appointed by reactionaries", and criticized the use of police against striking workers: July 11 and December 12, 1936. In the Marne, the prefect was slow to implement directives from Popular Front ministers : Le Travail de la Marne, April 17, 1937. In the Morbihan the prefect did all he could to aid clerical interests: Le Rappel du Morbihan, October 25, 1936. In the Basses-Pyrénées the Popular Front committee of Pau 
who were politically more astute: in the Vaucluse, the prefect praised Blum at a meeting of the department's Conseil général, making good an omission by the Radical president and winning the plaudits of the Socialist federation; in the Jura, the prefect called a rightist deputy to order, stating that as a representative of the government he could not tolerate a political attack on its head in his presence. ${ }^{1}$ Such cases, however, were rare.

There were, moreover, more serious incidents, which served to convince Socialist militants that an anti-republican prefectoral corps harbored potentially loyal servants of a French fascist regime. When on September 8, 1936 scabs from the struck Michelin tire works in Clermont-Ferrand occupied the prefecture of the Puy-de-Dôme, ostensibly to force police intervention against the striking workers, the Prefect Trouillot appears to have arranged to be out hunting. $\mathrm{He}$ returned in time, however, to order the Garde mobile to refrain from any action against the invaders. Scandalized, the Socialist federation phoned the ministry in Paris, and by evening Comrade-Minister Salengro had ordered the premises evacuated; the prefecture had in the meantime been surrounded by striking workers prepared to take the law into their own hands. ${ }^{2}$ Trouillot was unceremoniously sacked by Blum, but for the local Socialist federation it appeared to have required an abortive "fascist coup" at the prefecture to accomplish what should have been attended to much earlier. Trouillot had previously been under attack by the Left in the Puy-de-Dôme for alleged maladministration of departmental hospitals, unwillingness to implement Blum's decrees dissolving the fascist leagues, and failure to act, despite clear directives, against unjustified increases in prices. "Our comrades in power", the Socialist federation had solemnly warned, "will accomplish nothing if they allow their orders to be sabotaged by indolent prefects." 3 The September incident rapidly

officially protested the presence of the local prefect at a "fascist" demonstration: Le Travail, June 7, 1936, also July 5, 1936. The prefect of the Landes was charged by the same paper with failure to apply social legislation, September 6, 1936. In the Saône-et-Loire the prefect had arbitrarily fired fonctionnaives and favored the election of non-Socialist mayors: La Dépêche Socialiste, August 8, 1936. In the Deux-Sèvres the prefect lowered the salaries of deserving fonctionnaives while raising those of their "reactionary" chiefs: Le Travail, June 20, 1936. In the Vosges the prefect was simply described as a reactionary who sided consistently with management against labor: Le Travailleur Vosgien, July 18, 1936. The paper regularly carried a flyer "Monsieur le préfet: allez-vous-en!" thereafter.

1 Le Jura, June 13, 1936; Le Réveil Socialiste, November 19, 1936.

2 L'Auvergne Socialiste, September 12, 1936. Also Le Populaire, September 9, 1936.

3 Ibid., June 27, 1936. 
became an object lesson for Socialists in other departments with similar complaints.

In the absence of incidents of such magnitude, however, Socialist federations found themselves unable to dislodge administrators who often enjoyed the protection of locally entrenched political elites. In the Lot and the Somme the Socialist federations carried on bitter press campaigns against their prefects. The former department was a Radical fief and its deputies, from the conservative wing of that party, were all ministrables and men of great personal influence: Anatole de Monzie, Joseph Malvy, and René Besse. The Socialists of the Lot regarded the Prefect Jacquier as the creature of these politicians, a charge which found confirmation when Jacquier invalidated the election of a Socialist municipal councillor in Cahors, of which de Monzie was mayor, on a legal technicality having to do with the councillor's military service. ${ }^{1}$ Jacquier was further charged with political favoritism during the 1936 elections: he had allegedly made the distribution of funds, allocated by the ministry of agriculture for victims of the harvest failure of 1933 , contingent upon how districts voted. ${ }^{2}$ So serious was this charge that Blum had been obliged to take the matter up with Premier Sarraut in April 1936, and the Premier in turn convoked all the prefects to Paris to warn against any show of electoral partiality. Nor had the matter been allowed to rest there. Following the elections the Socialists tried unsuccessfully to deprive Malvy of his seat on the basis of the charges. ${ }^{3}$ To complicate matters further, Malvy, who was formally a part of the Popular Front majority, was the father-in-law of the Resident-General of Morocco, Marcel Peyrouton. Peyrouton's ouster had been demanded for years by the Socialists for alleged repression in his administration in North Africa.

Peyrouton was finally transferred by Blum in September, 1936, but there was no satisfaction to be had in the department of the Lot, and the result was a growing sense of helplessness among local Socialists who were unable to understand why power in their party on the national scene was not reflected locally. Embittered, the federation requested an extraordinary Socialist party congress for the purpose of holding the Blum government accountable for the poor showing of its first four months in office. ${ }^{4}$ Complaints continued throughout the year of

1 Le Travail du Lot, January 4, 1936. 2 Ibid., March 21 and April 4, 1936. ${ }^{3}$ See Journal Officiel (hereafter referred to as JO), Chambre, June 19, 1936, pp. 1470-1472.

4 Le Travail du Lot expressed impatience with continual postponement of administrative changes on September 5, 1936, warning that Popular Front electors were already deceived; on September 12 it again noted postponement bitterly; on September 19 it asked the special congress; and on October 24 it reflected that the souffle républicain had turned into a light breeze. 
"fascists" in the prefecture (the term was used rather broadly by Socialists in the period), and renewed charges of electoral manipulation involving a sub-prefect surfaced in a cantonal by-election in January 1937. But Jacquier remained in the Lot until May 1937 when he was "promoted" to prefect of the Dordogne, and his replacement in the Lot was found to be no improvement from the standpoint of the Socialist federation. ${ }^{1}$

In the Somme the Socialist paper, Le Cri du Peuple, had long charged that the upper reaches of the French administration were dominated by conservative coteries who regularly promoted so-called fascists. By September 1936 the paper denounced the Blum government for its inaction in the matter of personnel; in January 1937 the federal secretary Gontier warned that fifty years of right-wing administrative entrenchment in the French bureaucracy were being protected by the Radical party and the Senate. ${ }^{2}$ The government must make this clear to the public, Gontier admonished, or it would increasingly find its reforms blocked until it itself died of unpopularity. The battle with the local prefect of the Somme did not surface until March 1937, however, when the latter was charged by the Socialist Health Minister, Henri Sellier, with the creation of a committee of coordination in the department between national services of hygiene and social assistance. Working-class organizations were reportedly not consulted by the prefect in the formation of the committee and an "avowed reactionary" was named as its head. The Socialist federation immediately discovered that the same pattern of appointment held for the department's committee of price control, which brought Economics Minister Charles Spinasse into the dispute. A victory of sorts was achieved when Spinasse ordered the prefect to broaden representation on the price committee in the Somme, but the directive was found by local Socialists to be without tangible effect.

In its April 1937 congress, the federation of the Somme observed that "il n'y a pas une fédération, dans le parti, qui ne récrimine, avec raison, contre la composition des cadres gouvernementaux". The federation went on to vote a harsh list of demands upon the Socialist government. ${ }^{3}$ "Precise and imperative" orders must be passed on to qualified fonctionnaires by Socialist ministers, a thorough purge of the army, the magistrature, and all public administrations must be carried out, and more Socialist militants must be named to the personal cabinets of ministers. To see that all this was done improved liaison in the party between ministers and local militants must be effected.

1 Ibid., January 15, May 29 and July 3, 1937.

${ }^{2}$ Le Cri du Peuple, May 31 and September 25, 1936; January 10, 1937.

3 Ibid., April 17, 1937. 
In view of these widespread complaints, Blum's failure to give satisfaction to his party in the movement of prefects remains one of the less explicable sides of the Socialist exercise of power. To be sure, a majority of the prefects in office in the 1930's, like Jacquier in the Lot, were choices of the Radical party which had all but monopolized the Ministry of the Interior in recent years. Even more importantly, promotion had become in large part institutionalized within the corps; by the 1930's ninety-eight per cent of the prefects in office had been promoted from sub-prefectures. Yet the prefectoral corps was recognized to have been the most politically sensitive area of administration, and the government retained the absolute right to dismiss without explanation or cause as well as to make appointments from outside the ranks. Blum's first prefectoral movement of September 27, 1936, almost four months after he took office, involved seventeen lateral shifts and only five transfers out of the corps; it was hardly the "waltz" so eagerly awaited by party militants, and with the exception of the unhappy Trouillot in the Puy-de-Dôme, none of the dismissals correlated with the complaints aired in the Socialist press. ${ }^{1}$ On the other hand, at least one prefect who was under attack by his local federation (Charente) nevertheless received a promotion through the elevation of his department to second class, a change which the local Socialists stigmatized as "un défi" by their government. ${ }^{2}$ Roger Verlomme, a recently "baptized socialist" appointed to the position of director of personnel in the Ministry of the Interior by Roger Salengro, is credited by one historian with having saved many of his prefectoral colleagues from the fate they might have expected. It nevertheless remains remarkable that the Popular Front failed to make as great an impact on the corps as that made by the Radical government of Herriot which, in August 1924, shifted one-third of the prefects, transferring eight out of the corps entirely. ${ }^{3}$

1 JO, Lois et Décrets, September 27, 1936. Other than Trouillot, five prefects were listed as "appelé à d'autres fonctions", but none appear to have been the object of complaint in the press in their departments: these were M. Bidoux (Orne), M. Vié (Hautes-Pyrénées), M. Idoux (Creuse), M. Burnouf (Mayenne), and M. Monis (listed as "hors cadres"). Two lateral shifts do appear to have been influenced by party considerations: Angelo Chiappe, brother of the infamous former prefect of police, went from the Aisne to the Manche; Henri Graux, disliked in the Drôme, was moved to the Deux-Sèvres. Pierre Henry, Histoire des Préfets (Paris, 1950), pp. 317-318, interprets Graux's shift, however, as a promotion. All the new prefects appointed by Salengro came from subprefectures. a La Voix Socialiste, October 17, 1936, also October 31, 1936. "Socialist militants will fail to understand", the paper commented cryptically, "or will understand too well."

${ }^{3}$ Pierre Henry, pp. 290, 318. Siwek-Pouydesseau, pp. 76-79, defines a big shift after 1877 as involving twenty or more prefects; by this standard Herriot's and Combes's shifts were big, Blum's was not. 
Almost equal in volume to complaints about the prefectoral corps were Socialist attacks on the judiciary. While changes were more difficult in the Ministry of Justice owing to the legal irremovability of judges, the minister remained responsible for advancement, and charges of right-wing favoritism were taken seriously by Socialists because of the clearly insidious role played by the German judiciary during the rise of Hitler. There was an extensive catalogue of complaints among local Socialists. In Nice a leaguer arrested for trafficking in arms received only a two-month suspended sentence and a fine of 100 francs. In Grenoble judges acquitted two rightist newspapers of charges of inciting to violence, but condemned the Socialist newspaper for anarchist propaganda under the terms of the lois scélérates of 1892. A similar conviction was handed down in Besançon for an article in the Socialist newspaper that had appeared with impunity elsewhere in the country. In Bordeaux a Socialist militant was condemned for participation in a street brawl while fascist toughs were allegedly coddled by both police and judges. In the Chamber of Deputies Communists and Socialists complained that all too many judges regarded the parliamentary regime as "pourri". 1

Frustrated by statues protecting magistrates, Blum sought a remedy in legislation. A bill introduced in the Chamber on July 28, 1936 would have given the government powers to modify by decree the retirement ages of government personnel. The measure was described by its backers as a device to open up career opportunities for increasing numbers of youth in a time of economic hardship, but conservative deputies at once saw in it the much vaunted political purge promised by Popular Front rhetoric. An amendment was at once introduced from the opposition exempting the judiciary, bringing a frank admission by Socialist deputy Andre Le Troquer that the magistrates were precisely the objects of the legislation - the name of the unpopular first president of the Court of Cassation, Lescouvé, a bete noire of the left whose retirement Blum was eventually to obtain, was then hurled back and forth across the aisles. ${ }^{2}$ Passed by the Chamber, the bill finally emerged predictably emasculated by the Senate just before the closure of the first legislative session in August 1936. It bears remarking that Blum did not choose to stand his ground on this bill, alone among the measures which comprised his "first train" of legislation in the aftermath of the strike movement of June 1936, and all of which, with good or ill grace, the Senate passed.

1 L'Alerte, February 27, 1936; Le Droit du Peuple, May 22-23, 1937; Le Jura, March 7, 1936; L'Unité Socialiste, August 1, 1936; JO, Chambre, December 11, 1936, p. 3502.

2 JO, Chambre, July 28, 1936, p. 2185. 
The judiciary's rightist sympathies, in consequence, continued to rankle the Left throughout the year. Reviewing the problem shortly before Blum's resignation Radical Albert Bayet concluded that a truly Republican magistrature required, at the least, reforms in the method of recruitment and a period of suspension of the irremovability of the judges - the latter, he noted was not without precedent in the history of the Third Republic. ${ }^{1}$

Substantive changes do appear to have been made by the Blum cabinet in the police, whose administrative arrangement in separate parallel hierarchies has traditionally rendered them most easily subject to government control. One of the first officials to be sacked by the Popular Front was the "Chiappist" director of the Paris Police, Pierre Guichard. Prior to the July 14 demonstrations, Daladier, presumably under Blum's urging, replaced most of the officers charged with the security of the Paris region: General Moinier, Inspector of Gendarmerie; Col. Mazé, Commander of the Garde républicaine; Gen. Nicolet, Commander of the first legion of the Garde mobile; and Col. Vohl, Commander of the gendarmerie in Paris. All these dismissals were vigorously berated by conservative deputy Fernand-Laurent in the Chamber, and their effectiveness can probably be safely attested to by the repeated charges of police brutality against rightist demonstrators in the early weeks of the Blum government. ${ }^{2}$ Socialists further applauded the promotion of another "baptized socialist", sub-prefect Pierre Combes, to the Sûreté nationale, and the Blum government found a zealous servant in the new head of that investigative agency, M. Moitessier. ${ }^{3}$ Socialist charges of fascist complicity in the police were nevertheless revived following the unfortunate incidents at Clichy (March 1937) - but this was one area of his administration in which Blum was willing to defend his record, and one may take Minister of the Interior Marx Dormoy's dramatic uncovering of the rightist Cagoulard conspiracy in September 1937 as vindication of these claims. ${ }^{4}$

1 Quoted in Le Gers Socialiste, June 12, 1937, and widely circulated throughout the Socialist press.

2 JO, Chambre, June 20,1936, p. 1642; July 16, 1936, p. 1934. See also material on the demonstrations in Archives de la Préfecture de Police, AR 55, Carton 243, Folder 120. Police, according to outraged rightists, permitted the singing of "seditious" songs but forbade the Marseillaise.

3 Pierre Henry, p. 318; see the comments by André Blumel, in: Léon Blum, Chef de Gouvernement (Paris, 1967), p. 39.

- Even the Communists, according to police reports, expressed satisfaction with police handling of their demonstrations, and crowds on July 14 shouted "La Garde avec nous". Archives de la Préfecture de Police, ibid., Folder 121. All this was forgotten after Clichy, however, and Blum's claim at the party con- 
The Senate, having successfully blocked Blum's efforts to reform the judiciary, soon showed its intention of protecting other areas of administration as well. The dispute over the post office was characteristic, nor was it so minor a problem as might appear. The radio fell under the general administration of the PTT, and its importance as a propaganda weapon was clearly recognized. The PTT was among the government's largest employers of personnel, and the power of the unions over its operations had become a political issue. The previous occupant of the ministry, Georges Mandel, had conferred upon it a new dimension of importance, in particular by limiting the power of the unions over promotions and other personnel actions, and using the key posts in the Ministry to reward his political allies. ${ }^{1}$ Mandel was another bete noire of the Socialists, and by 1936 it was widely charged that he had turned the PTT over to a "coterie of fascists".

The Socialist Minister, Robert Jardillier, wanted nothing more than to restore the previous situation. Inevitably this meant undoing much of the extensive shifting of personnel that Mandel had undertaken; a special "committee of reparations" was established to review Mandel's changes and to reverse those which had been "irregular", i.e., accomplished contrary to the wishes of the unions which were permitted to dominate the committee. In all the committee reviewed some 950 cases of a total of approximately 35,000 personnel actions carried out under Mandel's auspices, and it took remedial action in less than 400 cases. Its work was abruptly cut short, however, by a nasty, sustained attack on Jardillier in the Senate in January 1937, an attack which clearly emanated from Mandel's political friends. ${ }^{2}$ Jardillier was accused, pursuant to an interpellation, of systematically firing anyone appointed by Mandel, of introducing a spirit of anarchy, hatred, and vengeance into the administration of the PTT, of causing undeserved hardship by the arbitrary geographical displacement of personnel, and of upsetting administrative stability by turning fonctionnaires into the "creatures of shifting majorities". 3

Jardillier's - and Blum's - defense was compromised by two embarrassing circumstances. The transfer of powers in the PTT had been accompanied by insults and harrassment of the former minister Mandel during his departure from his offices. The demonstration had

gress of Marseilles that he had purged the police was met with hoots. See Parti Socialiste, 35e Congrès national tenu à Marseille (Paris, 1937), p. 257.

1 John M. Sherwood, Georges Mandel and the Third Republic (Stanford, 1967), pp. 154-155.

2 Ibid., p. 195.

3 JO, Sénat, January 26,1937, p. 33. Sherwood accepts the politically motivated charges, referring to the "committee of reparations" as a "kangaroo court". 
apparently been orchestrated by the personnel, and all Jardillier could do was to offer his regrets while disclaiming any responsibility. Secondly, the management of the French radio had become a source of repeated right-wing complaints. While former Premier Doumergue had used the radio for monthly political broadcasts in 1934, this practice had ceased with the coming of Mandel. ${ }^{1}$ The Popular Front appeared to have opened the floodgates: Blum, Paul Faure, Léon Jouhaux, and a host of left-wing political leaders regularly had their speeches broadcast, while in newscast summaries of the press rightist opinion was often slighted. Critics of the Blum government saw at work here, not incorrectly, the sinister hand of Marceau Pivert, leader of the Socialist extreme left and Blum's charge de mission for radio and film propaganda. Pivert's energy and constant activities were greatly feared by the Popular Front's adversaries. Jardillier defended his personnel actions before the Senate, minor indeed in terms of the total number of 150,000 employees in the ministry, but the Senate was not to be dissuaded from demanding a special committee of inquiry into postal operations. Blum refused to accept the formation of such a committee, arguing that the Senate's regular committee was constitutionally empowered to look into any and all charges of abuse; the Senate in its turn agreed to leave matters to its regular committee only on condition that Jardillier cease at once all further mutations of personnel. ${ }^{2}$

Jardillier was attempting, with limited success, to secure the kind of ameliorative personnel action which was a widespread demand throughout the far-flung reaches of the French bureaucracy. Epuration for Socialists thus had positive content; it was not only a matter of cleaning the upper ranks of the administration, but also involved the rectification of numerous petty injustices at the lower levels. In particular the Doumergue, Flandin, and Laval governments of 1934-36 appear to have dismissed many school teachers for overt demonstrations of left-wing or pacifist sympathies. There were at least three cases involving Socialist militants which achieved some notoriety in party ranks in 1936: in the Aude, Blum's own constituency, a school teacher of Narbonne, M. Cerny, had been dismissed by the sub-prefect Pierre Voizard for participating in an anti-war demonstration. As if to rub salt in the wound Voizard was promoted to prefect of the Aude on the day Blum took office. In the Basses-

1 Sherwood, p. 154.

2 JO, Sénat, January 26, 1937, pp. 38-42. The Senate commission eventually reported its conclusions on April 13, 1938 - one assumes, coincidentally, during Blum's second government - and predictably substantiated all the charges made against Jardillier. See JO, Sénat, Annexes, April 13, 1938, No 277. 
Pyrénées a M. Verdier lost his job following conviction by the courts for pacifist activities. In the Cantal the secretary of the Socialist federation, Maurice Deixonne, was dismissed as lycée professor in Maurs in December 1934 for participation in a pacifist demonstration. ${ }^{1}$

The notoriety of these cases made some kind of government action imperative, although it was not always easy. In Blum's own constituency Cerny was reintegrated rapidly, winning the plaudits of the Socialist federation, which congratulated "the ministers of the Popular Front and Léon Blum in particular for having put an end to a flagrant injustice that had endured too long". The removal of the prefect Voizard, however, described as anti-worker, anti-socialist, and antirepublican, was not forthcoming, and protests discreetly disappeared from the Socialist press. In the Basses-Pyrénées Verdier was reintegrated, but the Socialist federation remained disgruntled that his original trial and conviction were not reversed. The Deixonne case in the Cantal took on political complications. The offender, a follower of Marceau Pivert, had been a candidate in the 1936 elections against Radical Paul Bastid, who was subsequently appointed by Blum Minister of Commerce. Since Deixonne had secured a post elsewhere, Bastid apparently opposed reintegration as a means of keeping his rival out of the department. The Socialist federation responded by threatening to demonstrate against Bastid when he returned to the department, and Deixonne himself used the occasion to editorialize against "imbéciles et malfaiteurs" at every level of the French administration who used their positions to oppose the Socialist government's innovative will.

Deixonne was finally restored to his post, but for countless other less-known cases only amnesty legislation could suffice. A sweeping amnesty bill was promised in the Popular Front program, but Blum failed to make an issue of its legislative acceptance, and like the bill lowering retirement ages for the judiciary, it was to remain a dead letter. It is hard to escape the conclusion that Blum failed his supporters in a very serious way by failing to press either of these bills during the initial package of legislation of July-August 1936, even, if necessary, to the detriment of some measures of social reform. Politics, after all, in all countries, is about patronage. Even the Communists showed concern with the issue of reintegration, seizing upon it along with others as a means of showing the inadequacy of the Blum government. Pierre Dadot, Communist deputy and himself a dismissed official of the ministry of war, pointed out in the Chamber on January 21, 1937

1 La République Sociale, June 4 and 26, 1936; Le Travail, June 28, 1936; Le Socialiste, June 21, July 12 and 26, August 16 and 23, September 6, 20 and 27, 1936. 
that without amnesty legislation the reintegration of victimized fonctionnaires required the convening of a board of inquiry of the same administrative personnel who had carried out the sanctions in the first place. ${ }^{1}$ Under such circumstances a Socialist government in power was hardly likely to make much difference.

That the Blum government failed to purge the higher reaches of the French internal bureaucracy to the satisfaction of its supporters does not of course constitute proof that its domestic policies were actually frustrated by hostile civil servants. The latter proposition was nevertheless perceived as truth in the Left; for purposes here that may be sufficient. The same belief in administrative sabotage existed with regard to the colonial, foreign affairs, and military bureaucracies, although from the standpoint of local politics and patronage these were of less immediate concern to Socialist militants. On the other hand it is in these crucial realms of statecraft that the evidence of real bureaucratic influence in the determination of government policy is more compelling.

Colonial affairs did not enjoy priority among concerns of the Blum government, and so it should perhaps not come as a surprise that the net effect the Popular Front had in the colonies was to demonstrate to indigenous populations that their hopes were no more likely to be served by governments of the Left in Paris than by governments of the Right. ${ }^{2}$ Projects for reform existed: a treaty of independence was negotiated with Syria, but remained unratified; the Blum-Viollette plan, which would have granted citizenship to increasing numbers of Algerian Moslems, remained a dead letter as well. The gradual acceptance by Socialists of the French assimilationist doctrine in colonial affairs meant that political reform was subordinated to the task of applying ameliorative social legislation and more humane administration to the indigenous populations. Thus such program as there was depended almost exclusively on the administrative bureaucracy for its implementation.

In fact eighteen of thirty colonial governors were replaced, including Peyrouton who was obliged to surrender Morocco to General Noguès. Although some of the new administrators were reputed to be of more liberal inclination (Noguès, however, excepted) there was little visible

1 See the debates on amnesty in JO, Chambre des Députés, January 21, 1937, p. 127.

2 William B. Cohen, "The Colonial Policy of the Popular Front", in: French Historical Studies, VII (1972), pp. 349-368. See also Manuela Semidei, "Les Socialistes français et le problème colonial entre les deux guerres", in: Revue Française de Science Politique, XVIII (1968), pp. 1115-1155. 
impact in the colonies, and repression remained severe throughout the Blum government's duration, including the censorship of newspapers in North Africa and the arbitrary arrest of adherents of political meetings, Socialists often included, in Indo-China. Where contrary government directives existed, top colonial officials either ignored them, or saw their own efforts sabotaged by lower-echelon personnel, all of which prompted Blum's Secretary of State Maurice Viollette to wonder aloud whether "the governors ruled the government" in the colonies, or the opposite situation prevailed. ${ }^{1}$ Government projects for reform in Algeria were stymied by the influence of radical élus on the Ministry of the Interior, and the desire of the colonial governor's office to placate local conservative opinion. Minister of Colonies Marius Moutet, the first Socialist to hold that post, was on much firmer ground defending the adequacy of his repressive apparatus in Algeria against senatorial critics, than in meeting the charges of leftwing critics of colonial repression at the time of his budgetary request in December 1936. The "civilizing mission" of France, Moutet lamely argued on the latter occasion, was to prepare backward populations for civil liberties which were clearly inappropriate to their present stage of evolution - as for charges of abuses, from distances of up to 15,000 kilometers public order must best remain the responsibility to those directly on the scene. Moutet's misplaced confidence in a traditional colonial bureaucracy, without even reviving once frequent tours of inspection, left him especially vulnerable to criticism from champions of the colonial populations:

"What did you write, Mr Minister, when you were in the opposition? [...] You attacked with violence the governments then in power and you made speeches which resembled singularly those for which you today reproach your adversaries."2

If colonial policy was of a low order of priority, foreign policy was of the highest, and the eruption of the Spanish issue ensured that foreign affairs would demand a disproportionate share of the Blum government's attentions. It is perhaps worth pointing out that there could be no clear definition of what constituted a "Socialist" policy in foreign affairs as appeared to be the case domestically, and by the time Blum came to office he was no longer substantially at odds with the broad lines of foreign policy being implemented by the Quai

1 Cohen, p. 377. See also the observations of Claude Julien, in: Léon Blum, Chef de Grouvernement, pp. 379-80. In fact, Julien claims, prefectoral services in Algeria openly encouraged displays of public opposition to projects of governmental reform.

2 JO, Chambre, December 15, 1936, p. 3629. 
d'Orsay. In Alexis Saint-Léger, moreover, Blum found a career official who appears to have genuinely sought to cooperate with him in a way totally devoid of ideological prejudice. The fact that Saint-Léger originated the scheme for non-intervention in Spain, and that that policy was enthusiastically supported by diplomatic personnel at the Quai, does not at all mean that Blum would not have come round to some similar solution anyway. ${ }^{1}$

It seems clear, however, that Blum's early resolve to aid the Spanish Republicans was opposed as much or more by the Quai as by the British, whose early role in the crisis now appears to have been minimal, or even by elements of the Radical party, whose alleged readiness to abandon the Popular Front coalition over Spain has never been demonstrated. ${ }^{2}$ When apprised by Pierre Cot of the Blum government's early intention to deliver planes to the loyalists, the political advisors at the Quai immediately offered the opinion that the furnishing of such arms, even to a legal government, constituted internal intervention in the affairs of another state presumably in violation of international law, in that the power of the supplier would thus be placed at the disposition of a foreign authority. ${ }^{3}$ While Blum was deciding to abandon his project of aiding the loyalists, he was no doubt further influenced by a dispatch from the French ambassador in Berlin, André François-Poncet, according to whom the delivery of arms to Spain would possibly cause serious "complications" in Franco-German relations. ${ }^{4}$ The ambassador added that the Germans were well aware of a split in France between the Premier and the Quai d'Orsay over Spanish policy, although he did not say how they came to this information.

One can only wonder, in any case, at the total impact of the lengthy, lucid, even elegant dispatches penned regularly from Berlin by François-Poncet during the 1930's. The ambassador was certainly not "almost a fascist", as the relatively unsophisticated US ambassador

1 Elizabeth R. Cameron, "Alexis Saint-Léger", in: Gordon Craig, ed., The Diplomats (New York, 1963), II, pp. 378-406. The support of French diplomatic personnel for the non-intervention pact is attested by political director of the Quai René Massigli, in: Léon Blum, Chef de Gouvernement, p. 362.

2 On British attitudes see David Carlton, "Eden, Blum, and the Origins of Non-Intervention", in: Journal of Contemporary History, VI (1971), No 3, p. 46. Peter Larmour, The French Radical Party in the 1930's (Stanford, 1967), pp. 206-207, absolves the Radicals of major responsibility. The best general account is Joel Colton's Léon Blum, Humanist in Politics (New York, 1966), pp. 245-267.

3 Documents Diplomatiques Français, 1932-1939, 2e Série (hereafter referred to as DDF), III, No 30, July 25, 1936.

4 DDF, III, No 28, July 25, 1936. 
Dodd thought. ${ }^{1}$ François-Poncet was, however, a conservative nationalist, had been a member of the majority in the Blue Horizon chamber of 1919, and remained very closely linked with the Comité des Forges. It is hard to tell how much of the disunity, division, and discord in French political life that he dwelt upon in his dispatches represented his own views and how much was the actual image of the Popular Front entertained by the Nazis. One knows, on the other hand, how concerned Blum was about France being thought abroad to be on the edge of revolution, weak, pitiful, or dissolving into crisis and anarchy such fears were ultimately to play a role in the Socialist leader's resignation.

Similar questions arise about the Popular Front's other crucially placed ambassadors. In Moscow Robert Coulondre enthusiastically sought, through diplomatic pressure, to secure an end to criticism of Spanish non-intervention by the French Communists, a suggestion to which the Russians bitterly objected and which made a farce of Blum's pose of candor and sincerity in his dealings with the PCF. In London Joseph Corbin, whose admiration for the Popular Front was no greater than François-Poncet's, regularly warned of, and perhaps exaggerated, British hostility to the conclusion of a Franco-Soviet military convention. ${ }^{2}$ But nowhere was the Blum government so ill served as by its ambassador in Spain, Jean Herbette, whose open admiration for Franco ran counter to everything which the Popular Front represented. While arguing in his dispatches for a pro-rebel policy by France - Franco was depicted by Herbette as an astute politician, nationalist but independent, who would undoubtedly prefer democratic bases of support - Herbette complained of French deliveries of supplies to the Republicans, advocated a break in relations over the loyalists' slowness to repatriate disillusioned French Republican volunteers, and warned that alliance with the loyalists was tantamount to an alliance with International Communism and an invitation to civil war on French territory. ${ }^{3}$

That the Blum government pursued a hands-off policy with regard to the army only further underscores the extent to which Socialist politicians fell into the general level of mediocrity characteristic of

1 Ambassador Dodd's Diary, ed. W. and M. Dodd (New York, 1941), p. 347.

2 On Coulondre DDF, III, No 472, November 12, 1936. Jules Moch described Corbin's hostility to the Popular Front in a personal interview, July 13, 1970.

3 US Ambassador Claude Bowers was scandalized by Herbette: My Mission to Spain (New York, 1954), pp. 296-297. For a representative sample of dispatches, DDF, III, Nos 237, 249, 316, 374, 399; IV, Nos 80, 133, 287, 323, 332, 403, 415; $\mathrm{V}, 66,95,147,167,236$. One can only wonder at what reaction Blum must have had to this material, the blatantly pro-Franco tone and substance of which had none of the subtlety of a François-Poncet or a Corbin. 
French governments of the 1930's. General Gamelin was always correct, courteous, and deferential in dealing with his political superiors, but he provided an ideal cover for the psychological and ideological conditioning of the officer corps which resulted in its increased politicization. Gamelin went so far as to protest Minister of Defense Daladier's removal of General Gerodias, who in January 1937 circulated to all army units a spurious document detailing alleged plans for a projected Communist coup in France - the document originated with the then nascent Cagoulard conspiracy. ${ }^{1}$ Blum most likely was not even aware of the incident; so removed was the Premier from military affairs in 1936-37, that he thought mechanized units like those advocated by Colonel de Gaulle in a personal interview with him in September 1936 were in fact being created. ${ }^{2}$ The lack of armoured units ultimately angered the Socialist party far less than the fact that with Daladier's approval officers continued to forbid the reading of the left-wing press in the barracks, but both point up what was perhaps the Blum government's most serious failing. The only exception to this picture appears to have been owing to the Radical Minister of Aviation, Pierre Cot, who ousted seven of nine generals of division and effected 170 mutations of lower ranks in the air force during the Blum government's first six weeks. Cot virtually admitted, amid vociferous conservative protests in the Chamber, that his criteria for removal were right-wing political activities of the officers in question, or insufficient belief on their part in the military importance of air power. ${ }^{3}$ Daladier, who rushed to Cot's defense in the Chamber, was obliged on the same occasion to defend his own inaction in the matter of personnel from attack by the Left. But Daladier on another occasion told Gamelin, in a moment of anger, that he regretted not having carried out purges in the army as extensive as those of the Aviation Minister. ${ }^{4}$

Cot's changes in the air force, like Jardillier's attempted housecleaning of the post office, was most significant for its placing in relief the government's inaction in other administrations. In general the Blum government acted too little to satisfy its constituents and probably too little to secure loyal and adequate implementation of its

1 The incident is recounted in General Bourret, La Tragédie de l'Armée française (Paris, 1947), pp. 137-138; General Gamelin, Servir (Paris, 1946), II, pp. 259-266; and Philip Bankwitz, Maxime Weygand and Civil-Military Relations in Modern France (Cambridge, 1967), p. 267.

2 Blum admitted this in his post-war testimony: France, Assemblée Nationale, Rapport fait au nom de la Commission chargée d'enquêter sur les événements survenus en France de 1933 à 1945, par M. Charles Serre (Paris, 1947), I, p. 219. ${ }^{3}$ Cot's changes were debated on at least two separate occasions: JO, Chambre, July 16, 1936, pp. 1934-1935; January 26, 1937, pp. 211-213.

4 Gamelin, Servir, II, p. 263. 
own policies. The total effect was not mitigated by changes in the police, or by several highly publicized individual cases that did occur, such as the removal of Lescouve from the post of first president of the Court of Cassation, or the ousting of François-Latour as Commissioner of the Paris exhibition of 1937 for having written a public letter of sympathy to Charles Maurras on the occasion of the latter's imprisonment. Blum also forced the Agence Havas, whose dominant position in the news industry was dependent upon government cooperation, to rid itself of the services of Pierre Guimier, an outspoken government critic, and the Premier ousted M. Tannery, author of Laval's hated decree laws of 1935, from the post of governor of the Bank of France. These actions all paled into insignificance, however, when the infamous Inspectors of Finance, financially orthodox agents of the " 200 families" Paul Baudouin, Wilfrid Baumgartner, and Charles Rist, appeared prominently in association with Blum's "pause" on any new reforms or expenditures and his loan in March 1937 at guaranteed rate of exchange. ${ }^{1}$ When these three gentlemen all ostentatiously resigned their functions ten days prior to the culmination of the financial crisis which toppled Blum in June 1937, all the worst suspicions of the Left about the occult powers of conservative bureaucrats appeared to have been confirmed.

The reasons for the Blum government's inadequacies in matters of administration require further study. The historian cannot afford the luxury of refuge in popular theories of technological determinism and bureaucratic omnipotence. The generally mediocre level of the Socialist Ministers, despite some individual exceptions in the Blum cabinet (most notably Jean Zay, the Minister of Education), must be noted, not in the sense of the lack of technical expertise, as has been asserted by some historians, but rather in terms of strength of character and selfconfidence. ${ }^{2}$ An obvious case in point was the deplorable impression made by the suicide of Minister of the Interior Roger Salengro in December 1936, as a result of personal attacks for alleged desertion during World War I. The Minister of the Interior was in many ways individually the most powerful politician in France, and it is curious

1 On the above dismissals L'Echo de Paris is a good source, November 5 and 7, 1936. For a conspiratorial theory of Blum's resignation, Daniel Guérin, Front Populaire, révolution manquée (Paris, 1963), pp. 166-167.

2 See Jacques Ellul, The Political Illusion (New York, 1972), pp. 136-63. Crozier, however, discounts the impcrtance of technicians and emphasizes the human elements which render bureaucracy subject to political control. On Zay's innovative experiments see John E. Talbott, The Politics of Educational Reform in France, 1918-1940 (Princeton, 1969), pp. 205-245. 
and symptomatic that his strong arm fell upon factional publications of the Left during the Popular Front but not those of the Right, despite the scurrilous attacks. The numerous structural and political obstacles to extensive changes in personnel were magnified by the Blum government's legalistic scruples, and its unwillingness to perpetuate the same kinds of injustices which it had ascribed to previous governments of the Right. Finally it must be remembered that many officials, no matter how much they were opposed to the Popular Front and were personally unpopular with its constituents, were capable of serving it loyally even as they may have served a Vichy regime later. Assertions like those of André Blumel, however, who claims he found virtually the whole of the administration to be fully cooperative, are rather indicative of the enormous gap in perceptions separating the Socialist oligarchy from the mass of militants they purported to represent. ${ }^{1}$

George Lichtheim has recently called attention to the general theoretical naivety and practical ineptitude demonstrated by SocialDemocracy in the inter-war period with regard to the challenge of political power. The dominant Kautskian interpretation of Marxism, which was shared by the French Guesdists, was too narrowly sociological in its approach to power: the evolution of social classes, according to this widely-accepted view, determined the form of the state; a working-class majority in the nation must of necessity be translated into a socialist polity. ${ }^{2}$ This formulation encouraged a placid acceptance of existing political forms by Socialist reformists, and a naive faith that whatever its form the state must eventually disappear, by revolutionists. Thus the Guesdist Jean Zyromski could condemn theorization about political reform as a "bourgeois pastime"; the only Socialist ever to give serious consideration to the forms of political action was Blum himself, before he became a Socialist leader, however, and his efforts in that connection were viewed as a drawback rather than a strength from the standpoint of rank-and-file Socialists. ${ }^{3}$ In France the Jauressian tradition and a heritage of republican defense brought an even greater attachment to the existing Republican synthesis among moderate Socialists, while the anarcho-syndicalist

1 Blumel's assertion that the administration was on the whole cooperative was flatly challenged by Pierre Cot, in: Léon Blum, Chef de Gouvernement, pp. 39. 92-93.

2 A Short History of Socialism (New York, 1970), p. 246.

3 Jean Zyromski, Les Formations politiques de la France contemporaine et l'action du Parti socialiste (Paris, 1931), pp. 12-27; Lucien Sfez, "Les Idées Constitutionelles des Socialistes français (1944-1964)", in: Jean Gicquel and Lucien Sfez, Problèmes de la Réforme de l'Etat en France depuis 1934 (Paris, 1965), pp. 213-40. 
tradition still prevalent in the unions repudiated political action altogether. Neither component of indigenous left-wing tradition offered any kind of guide in coming to grips with the problems of managing the Napoleonic bureaucracy which governed France.

It is worth recording that, under the pressure of Socialist militants, the Blum government came to recognize its inadequacies. The subject of an administrative purge dominated a conference of federation secretaries of the SFIO in October 1936, and complaints were repeated at the November National Council of the party. ${ }^{1}$ Blum, on the latter occasion, offered two kinds of defense: more had been done than was immediately perceptible, he argued, and this was slow work, more time was required, "one does not undo in five months the accumulated work of fifty years". Nevertheless the issue remained alive, and it was picked up by the party's dissident factions led by Marceau Pivert and Jean Zyromski; unlike the questions of Spain or the government's economic policies, moreover, it drew an open admission of insufficient action from the party leadership. A propaganda pamphlet drawn up for Socialist militants in the spring of 1937 attributed an "enormous power of resistance" to the bureaucracy. It went on:

"We are quite willing to admit that certain services could have done better, meaning by that the calling to order of those who too often forget their indispensible loyalty to republican institutions and the pitiless ousting of those who would turn a deaf ear. But nothing is yet lost, more can be done tomorrow. It is a delicate terrain. We must avoid arbitrariness and injustice. [...] we cannot govern like fascists." 2

A resolution of the Socialist party leadership, sponsored by Blum and Paul Faure for the Marseilles congress of the party in July 1937, and drawn up while the government was still in office, addressed this question. It lamely declared that "the action of the [Blum] government in the ensemble of the administrations has been too weak". ${ }^{3}$ The issue contributed to a general climate of protest by Socialists against their government, the explosion of which Blum was only able to forestall at Marseilles by resigning.

Two further observations impose themselves by way of summary. First the enormous importance attributed to changes in administrative personnel in 1936 and 1937 highlights the deep implantation of the Popular Front in local politics. The mass aspirations for national economic and social legislation, the drama and the tragedy of Blum's

1 Le Populaire, October 9 and November 9, 1936.

${ }^{2}$ Le Gouvernement à Direction Socialiste (Limoges, 1937), p. 80.

Le Populaire, June 4, 1937. 
foreign policy, ought not to be allowed to obscure more mundane political realities - the struggle between classes was indeed, outside the cabinet, the struggle for places, and a great source of disillusionment in the era lies in the fact that the victors felt deprived of their spoils. Secondly the twin issues of épuration and reintegration constituted in themselves an enormous pressure for the Blum government to place as its number one priority, above either economics or Spain, its own survival. Only a prolonged period in office could have won the cooperation of many recalcitrant fonctionnaires who otherwise counted on a quick disappearance of the Socialists from the scene; it would also have allowed the recruitment and promotion of more pliable officials while it habituated a nation to the future reality of Socialist government. The category of the "occupation" of power, so carefully expounded by Blum, provided ample theoretical justification for such a course of action, given the exceptional crisis conditions of the 1930's. It is this that made the coming months such a source of disillusionment for Blum's party and for the French Left as a whole. And it is the inadequacy of the Blum government from the perspective of its own constituents, rather than its presumed failure, certainly no greater than any non-Socialist government of the 1930's from a global perspective, which may one day come to be recognized by historians as its most enduring legacy. 